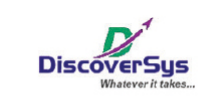

Published by DiscoverSys

\section{Determinants of anemia in women of reproductive age in Indonesia: Secondary data analysis of the 2018 Indonesia Basic Health Research}

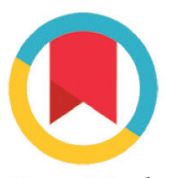

CrossMark

\author{
Putu Sri Utami, ${ }^{1 *}$ Luh Seri Ani, ${ }^{2}$ Dinar Saurmauli Lubis, ${ }^{2}$ Dewa Nyoman Wirawan ${ }^{2}$
}

\section{ABSTRACT}

Background and purpose: Anemia in women is a public health concern that is prevalent in developing countries. Women of reproductive age (WRA) frequently suffer from anemia, which can contribute to morbidity and mortality of mothers and their infants. The purpose of this study was to determine the prevalence and factors associated with anemia among women of reproductive age (WRA) in Indonesia.

Methods: This study uses secondary data from the 2018 Indonesia Basic Health Research or Riset Kesehatan Dasar (Riskesdas) which was conducted in 34 provinces in Indonesia. The number of samples analyzed was 3,677 women aged 15-49 years who had data from interviews, measurements of height, weight, results of malaria tests, and hemoglobin levels. Data analysis was performed using multivariate logistic regression to determine the relationship between anemia and individual characteristics, nutritional and health status as well as environmental conditions and health service accessibility.

Results: The prevalence of anemia among WRA in Indonesia was 25.3\% (95\%Cl: 23.9-26.7). Factors which found to be associated with the prevalence of anemia in WRA were age $<20$ years ( $A 0 R=3.44 ; 95 \% \mathrm{Cl}: 2.22-5.35 ; \mathrm{p}<0.001)$, underweight $(A O R=1.48$; $95 \% \mathrm{Cl}: 1.08-2.05 ; p=0.017)$, obesity $(A 0 R=0.68 ; 95 \% \mathrm{Cl}: 0.56-$ $0.81 ; \mathrm{p}<0.001)$ and the use of hormonal contraception ( $A O R=0.53$; $95 \% \mathrm{Cl}: 0.44-0.64 ; \mathrm{p}<0.001)$.

Conclusion: Based on the prevalence, anemia among WRA in Indonesia is categorized as a moderate public health concern and the most common risk factor for anemia was WRA aged $<20$ years and underweight. To reduce the incidence of anemia in WRA, interventions should be targeted at WRA aged $<20$ years and underweight.

Keywords: anemia, women of reproductive age, underweight, Indonesia, Riskesdas

Cite this Article: Utami, P.S.U., Ani, L.S., Lubis, D.S., Wirawan, D.N. 2020. Determinants of anemia in women of reproductive age in Indonesia: Secondary data analysis of the 2018 Indonesia Basic Health Research. Public Health and Preventive Medicine Archive 8(2): 86-91. D0I: 10.15562/phpma.v8i2.301

${ }^{1}$ School of Midwifery, Faculty of Sport and Health Sciences, Ganesha Education University ${ }^{2}$ Department of Public Health and Preventive Medicine, Faculty of Medicine, Udayana University

${ }^{*}$ Correspondence to: Putu Sri Utami; School of Midwifery, Faculty of Sport and Health Sciences, Ganesha Education University; utami.id11@gmail.com

\section{INTRODUCTION}

Globally, the number of women with anemia was reported to be 528.7 million in 2011. ${ }^{1}$ In higherincome countries, the prevalence of anemia is around 9\%, but in low-income countries, the prevalence of anemia is much higher at around $43 \% .^{2}$ The prevalence of anemia in pregnant women and women of reproductive age (WRA) aged 15-49 years were reported to be higher at 38\% (32.4 million) and 29\% (496 million), respectively. The majority of them reside in Africa and Asia accounting for about $85 \%$ of the total global incidence of anemia. ${ }^{1}$

Globally, anemia is estimated to contribute to more than 115,000 maternal deaths, 591,000 perinatal deaths per year and decreased productivity due to impaired work capacity, cognitive impairment and increased susceptibility to infections, which ultimately create a substantial economic burden. ${ }^{1}$ To overcome these problems, the World Health Organization (WHO) developed targets to reduce the prevalence of anemia in WRA by $50 \%$ in 2025 through early identification, measurement and increasing coverage of anemia prevention, control and treatment. ${ }^{3}$

In several countries, a fairly large reduction in the prevalence of anemia has been achieved, however, the overall reduction in the prevalence of anemia in WRA has not been sufficient. ${ }^{3}$ The prevalence of anemia in countries in Southeast Asia has been mixed. In 2016, the World Bank reported the lowest prevalence of anemia in WRA in the Philippines at $14.9 \%$ and the highest in Laos at $54.6 \%$, while Indonesia was ranked sixth at 28.2\%. Even though this is not classified as a high prevalence, anemia is still a moderate public health problem, especially for women aged 15-49 years because the prevalence is more than $20 \%$. Therefore, it is important to monitor the prevalence and determinants of anemia in Indonesia from time to time to better understand the changing burden of anemia and so as to be able to plan appropriate countermeasures in order to achieve the target set by WHO at 2025 .

Determinants of anemia in the population are a complex interaction between political, ecological, social and biological factors. ${ }^{5}$ Therefore, reducing 
the incidence of anemia requires an integrated approach to address these factors so that this issue can be well controlled. Research on the factors associated with anemia in Indonesia has been widely carried out but with a small sample size and a limited research area so that the results cannot be generalized throughout Indonesia, especially considering Indonesia's vast territory and very diverse population. Therefore, it is necessary to conduct research on a broader scale with a large sample so that the results can be representative of all regions of Indonesia regarding the factors associated with the incidence of anemia in WRA in Indonesia. This study aims to identify the determinants of anemia in WRA in Indonesia by analyzing the data from the 2018 Indonesia Basic Health Research or Riset Kesehatan Dasar (Riskesdas).

\section{METHODS}

This study uses secondary data from the 2018 Riskesdas which was obtained after submitting an application and obtaining a data use permit from the Ministry of Health of the Republic of Indonesia. Riskesdas is a national scale survey representing all areas of Indonesia. The 2018 Riskesdas was conducted on 3,678 women of reproductive age (15-49 years) using a two-stage stratified sampling. Detailed information about the research design, sample size calculation, instruments and methods of data collection and other survey procedures are available in the 2018 Riskesdas report. ${ }^{6}$

The design of the 2018 Riskesdas was crosssectional survey in which women who met the criteria were interviewed using a questionnaire and went through the measurements of their height and weight as well as malaria tests and anemia status. In our analysis, eligible subjects were non-pregnant women aged 15-49 years and having complete data from interviews and measurements available in the 2018 Riskesdas data set. Subjects excluded were those with incomplete data from interviews and/ or measurement results, therefore the analyzed subjects amounted to 3,677 .

The dependent variable was anemia status among WRA. The independent variables consisted of three main variables, namely the WRA characteristics, nutritional and health status, environmental conditions and accessibility to health services. WRA characteristics included age, education level, occupation, marital status, number of children and area of residence. The variables of nutritional and health status included nutritional status, malaria infection, tuberculosis (TB) infection, and the type of contraception used. Variables of environmental conditions and accessibility to health care providers consisted of access to hospitals, access to primary public health services, access to private health services and sources of drinking water.

In our analysis, age was grouped into three, namely <20, 20-35 and $>35$ years. The level of education was grouped into low, middle and high education. The work status was divided into two, namely working and not working, and the marital status of being married and divorced. The number of children was grouped into four, namely no children (none), 1-2, 3-4, >4 children. The area of residence was grouped into urban and rural. The nutritional status was determined by body mass index (BMI) which were categorized into underweight, normal, overweight and obese. Malaria infection was categorized into negative and positive, while TB infection into yes and no. The use of contraceptives was grouped into no use, Intrauterine Device (IUD), tubectomy and hormonal contraception. Access to hospitals and primary public or private health services were assessed by three components, namely the type of transportation, the length of time to commute and the costs incurred for transportation, and then categorized to be easy, difficult and very difficult. Sources of drinking water were categorized as protected and unprotected.

Bivariate analysis was performed to display data on the characteristics of WRA and other variables with the incidence of anemia and the statistical tests were carried out by using chi-square with a value of $\mathrm{p} \leq 0.05$. The results of the bivariate analysis were used to select the variables which were included in the multivariate model. Multivariate analysis was carried out by using binary logistic regression with the enter method to obtain the Adjusted Odds Ratio (AOR) of each variable.

This study has been approved by the Ethics Committee of the Faculty of Medicine, Udayana University/Sanglah General Hospital with an ethical clearance number: 445/UN/14.2.2.VII.14/LP/2020 on 26 February 2020.

\section{RESULTS}

Out of 3,677 WRA involved in the analysis, prevalence of anemia among WRA in Indonesia in 2018 was $25.3 \%$ (95\%CI: 23.9-26.7). Table 1 presents the characteristics of WRA and it shows that most respondents are 20-35 years old (68.3\%), have secondary education level (58.5\%), unemployed (64.3\%), married (97.5\%), have 1-2 children (67.6\%), live in urban areas (53.9\%), have normal nutritional status (47.4\%). Meanwhile, almost all of the WRA have a negative malaria test (99.5\%), do not have a history of tuberculosis in the last 1 year $(99.7 \%)$, are using hormonal contraception 
(67.0\%), have difficult access to hospitals (39.6\%), easy access to government and private primary health care services (36.4\% and 35.0\%) and $72.3 \%$

Table 1. Sociodemographic characteristics of WRA

\begin{tabular}{lcc}
\hline \multicolumn{1}{c}{ Variable } & $\mathbf{n}$ & $\%$ \\
\hline Age (years) & 92 & 2.5 \\
$\quad<20$ & 2,511 & 68.3 \\
$20-35$ & 1,074 & 29.2 \\
$>35$ & & \\
Education & 316 & 8.6 \\
$\quad$ High & 2,153 & 58.5 \\
Middle & 1,208 & 32.9 \\
$\quad$ Low & & \\
Employment status & 1,312 & 35.7 \\
$\quad$ Employed & 2,365 & 64.3 \\
$\quad$ Unemployed & & \\
Marital status & 3,585 & 97.5 \\
$\quad$ Married & 92 & 2.5 \\
$\quad$ Divorced & & \\
Number of children & 26 & 0.7 \\
$\quad$ None & 2,485 & 67.6 \\
1-2 & 1,031 & 28.0 \\
3-4 & 135 & 3.7 \\
$\quad>4$ & & \\
Area of residence & 1,982 & 53.9 \\
$\quad$ Urban & 1,695 & 46.1 \\
$\quad$ Rural & $\mathbf{3 , 6 7 7}$ & $\mathbf{1 0 0 . 0}$ \\
\hline Total & & \\
\hline
\end{tabular}

Table 2. Nutritional status, health status and environmental condition of WRA

\begin{tabular}{|c|c|c|}
\hline Variable & $\mathbf{n}$ & $\%$ \\
\hline \multicolumn{3}{|l|}{ Nutritional status } \\
\hline Normal & 1,774 & 47.4 \\
\hline Underweight & 192 & 5.3 \\
\hline Overweight & 562 & 15.3 \\
\hline Obese & 1,179 & 32.0 \\
\hline \multicolumn{3}{|l|}{ Malaria test results } \\
\hline Negative & 3,660 & 99.5 \\
\hline Positive & 17 & 0.5 \\
\hline \multicolumn{3}{|l|}{ History of TBC } \\
\hline No & 3,665 & 99.7 \\
\hline Yes & 12 & 0.3 \\
\hline \multicolumn{3}{|l|}{ Contraceptive $^{\star}$} \\
\hline None & 762 & 21.2 \\
\hline IUD & 261 & 7.3 \\
\hline Tubectomy & 163 & 4.5 \\
\hline Hormonal & 2,405 & 67.0 \\
\hline \multicolumn{3}{|l|}{ Access to hospital } \\
\hline Easy & 1,167 & 31.7 \\
\hline Difficult & 1,454 & 39.6 \\
\hline Very difficult & 1,056 & 28.7 \\
\hline \multicolumn{3}{|c|}{ Access to public health services } \\
\hline Easy & 1,338 & 36.4 \\
\hline Difficult & 1,182 & 32.1 \\
\hline Very difficult & 1,157 & 31.5 \\
\hline \multicolumn{3}{|c|}{ Access to private health services } \\
\hline Easy & 1,287 & 35.0 \\
\hline Difficult & 1,131 & 30.8 \\
\hline Very difficult & 1,259 & 34.2 \\
\hline \multicolumn{3}{|l|}{ Drinking water sources } \\
\hline Protected & 3,394 & 72.3 \\
\hline Unprotected & 283 & 7.7 \\
\hline Total & 3,677 & 100.0 \\
\hline
\end{tabular}

* The number of sample 3,591 because there was some missing data. have an access to protected drinking water sources (Table 2).

Table 3 and 4 present a cross-tabulation between anemia and the determinant variables. From the socio-demographic factors, age $(\mathrm{p}<0.001)$ and education level $(\mathrm{p}=0.043)$ are significantly associated with anemia (Table 3 ), meanwhile, nutritional status $(\mathrm{p}<0.001)$ and use of contraceptives $(\mathrm{p}<0.001)$ are also significantly associated with the prevalence of anemia in WRA (Table 4). Compared to the other groups within the factors, the prevalence of anemia is highest among WRA ages $<20$ years ( $55.4 \%)$, high education (27.8\%) - (Table 3), underweight (38.5\%) and use of IUD contraceptive (35.2\%) - (Table 4).

Table 5 presents the results of multivariate analysis using logistic regression with the enter method. Factors that are associated with anemia after being adjusted with other factors were age, nutritional status and use of contraceptive. WRA who are $<20$ years have an increased odd of anemia by 3.4 times compared to those aged 20-35 years (AOR=3.444; 95\%CI: 2.216-5.351; $\mathrm{p}<0.001)$. Based on nutritional status, WRA who are underweight have an increased odd of anemia by 1.5 times compared to WRA with normal $\mathrm{BMI}$ ( $\mathrm{AOR}=1.484$; 95\%CI: 1.075-2.050; $\mathrm{p}=0.017$ ), whilst being obese reduced the odd of anemia by $33 \%$ ( $\mathrm{AOR}=0.672$; 95\%CI: $0.560-0.807 ; \mathrm{p}<0.001)$ compared to the reference groups. Meanwhile, the use of hormonal contraceptive significantly reduced the odd of anemia by almost $50 \%$ compared to those who are not using any contraception $(\mathrm{AOR}=0.525 ; 95 \% \mathrm{CI}$ : 0.438-0.630; $\mathrm{p}<0.001)$.

\section{DISCUSSION}

The prevalence of anemia among WRA in Indonesia in this analysis was $25.3 \%$. The prevalence identified in this study is lower when compared to the average prevalence of anemia among WRA globally $(32.8 \%) .{ }^{4}$ From the analysis we found factors that are associated with anemia were age, nutritional status and use of contraception.

In our analysis, the factor most strongly associated with anemia was age, that is, the group of women aged $<20$ years. Similar findings were found in Nepal, where the risk of anemia was found to be higher in younger women. ${ }^{7}$ This may be because currently married women $<20$ years of age had been anemic since before they were married or in adolescence. Adolescents have a higher demand for iron particularly during the period of growth spurt and excessive blood loss during menstruation. This demand will be doubled during pregnancy due to the rapid growth of the placenta and the fetus, and during breastfeeding. This situation may cause married women aged $<20$ years to have a higher 
Table 3. Proportion of anemia based on WRA socio-demographic characteristics

\begin{tabular}{|c|c|c|c|c|c|}
\hline \multirow{2}{*}{ Variable } & \multicolumn{2}{|c|}{ Anemia } & \multicolumn{2}{|c|}{ No anemia } & \multirow[t]{2}{*}{$\mathbf{p}$} \\
\hline & $n$ & $\%$ & $\mathrm{n}$ & $\%$ & \\
\hline Age (years) & & & & $<0.001$ & \\
\hline$<20$ & 51 & 55.4 & 41 & 44.6 & \\
\hline $20-35$ & 626 & 24.9 & 1,885 & 75.1 & \\
\hline$>35$ & 252 & 23.5 & 822 & 76.5 & \\
\hline Education & & & & 0.043 & \\
\hline High & 88 & 27.8 & 228 & 72.2 & \\
\hline Middle & 566 & 26.3 & 1,578 & 73.7 & \\
\hline Low & 275 & 22.8 & 933 & 77.2 & \\
\hline Employment status & & & & 0.143 & \\
\hline Employed & 313 & 23.9 & 999 & 76.1 & \\
\hline Unemployed & 616 & 26.0 & 1,749 & 74.0 & \\
\hline Marital status & & & & & 0.503 \\
\hline Married & 903 & 25.2 & 2,682 & 74.8 & \\
\hline Divorced & 26 & 28.3 & 66 & 71.7 & \\
\hline Number of children & & & & & 0.051 \\
\hline 0 & 11 & 42.3 & 15 & 57.7 & \\
\hline $1-2$ & 626 & 25.2 & 1,859 & 74.8 & \\
\hline $3-4$ & 249 & 24.2 & 782 & 75.8 & \\
\hline$>4$ & 43 & 31.9 & 92 & 68.1 & \\
\hline Area of residence & & & & & 0.846 \\
\hline Urban & 503 & 25.4 & 1,479 & 74.6 & \\
\hline Rural & 426 & 25.1 & 1,269 & 74.9 & \\
\hline
\end{tabular}

Table 4. Proportion of anemia based on WRA nutritional status, health status and environmental factors

\begin{tabular}{|c|c|c|c|c|c|}
\hline \multirow{2}{*}{ Variable } & \multicolumn{2}{|c|}{ Anemia } & \multicolumn{2}{|c|}{ No anemia } & \multirow[t]{2}{*}{ p } \\
\hline & $\mathbf{n}$ & $\%$ & $n$ & $\%$ & \\
\hline Nutritional status & & & & & $<0.001$ \\
\hline Normal & 488 & 28.0 & 1,256 & 72.0 & \\
\hline Underweight & 74 & 38.5 & 118 & 61.5 & \\
\hline Overweight & 129 & 23.0 & 433 & 77.0 & \\
\hline Obese & 238 & 20.2 & 941 & 79.8 & \\
\hline Malaria test results & & & & & 0.693 \\
\hline Negative & 924 & 25.2 & 2,736 & 74.8 & \\
\hline Positive & 5 & 29.4 & 12 & 70.6 & \\
\hline History of TB & & & & & 0.807 \\
\hline No & 923 & 25.2 & 2,736 & 74.8 & \\
\hline Yes & 6 & 50.0 & 6 & 50.0 & \\
\hline Contraceptive $^{*}$ & & & & & $<0.001$ \\
\hline None & 258 & 33.9 & 504 & 66.1 & \\
\hline IUD & 92 & 35.2 & 169 & 64.8 & \\
\hline Tubectomy & 47 & 28.8 & 116 & 71.2 & \\
\hline Hormonal & 505 & 21.0 & 1,900 & 79.0 & \\
\hline Access to hospital & & & & & 0.170 \\
\hline Easy & 282 & 24.2 & 885 & 75.8 & \\
\hline Difficult & 358 & 24.6 & 1,096 & 75.4 & \\
\hline Very difficult & 289 & 27.4 & 767 & 72.6 & \\
\hline Access to public health services & & & & & 0.239 \\
\hline Easy & 328 & 24.5 & 1,010 & 75.5 & \\
\hline Difficult & 288 & 24.4 & 894 & 75.6 & \\
\hline Very difficult & 313 & 27.1 & 844 & 72.9 & \\
\hline $\begin{array}{l}\text { Access to private basic health } \\
\text { services }\end{array}$ & & & & & 0.375 \\
\hline Easy & 320 & 24.9 & 967 & 75.1 & \\
\hline Difficult & 274 & 24.2 & 857 & 75.8 & \\
\hline Very difficult & 335 & 26.6 & 924 & 73.4 & \\
\hline Drinking water source & & & & & 0.286 \\
\hline Protected & 850 & 25.0 & 2,544 & 75.0 & \\
\hline Unprotected & 79 & 27.9 & 204 & 72.1 & \\
\hline
\end{tabular}

*The number of samples is 3,591 because there was missing data risk of developing anemia. The 2017 Indonesia Demographic and Health Survey or Survey Demografi dan Kesehatan Indonesia (SDKI) reports that $7 \%$ of women aged $15-19$ already become a mother. Another study using data from the 2017 SDKI found that pregnant women aged $<20$ and $>35$ years had a 6.6 times greater risk of developing anemia. ${ }^{8}$ In other studies, in Magalaya ${ }^{9}$ and India ${ }^{10}$, age was also found to be associated with anemia, where in Magalaya the highest risk of anemia occurred at 20-24 years, while in India women aged 25-35 years were 3.3 times more likely to experience anemia. This is probably because this age group has a high fertility rate.

Another factor related to anemia is nutritional status where underweight women are more likely to have anemia whilst obese women are less likely to have anemia. Similar findings were also reported in China ${ }^{11}$ and Taiwan. ${ }^{12}$ Obese and overweight women were found to have higher intakes of vitamin $\mathrm{C}$ and iron. ${ }^{11}$ Undernourished women were more likely to be deficient in essential micronutrients associated with anemia. A study in Taiwan found a positive association between body mass index (BMI) with serum ferritin and hemoglobin levels, that is, the higher the BMI the higher the serum ferritin and hemoglobin levels among women age $\geq 19$ years. ${ }^{12}$ Overweight (odds ratio, OR: 0.365 (0.181-0.736)) and obese (OR: $0.480(0.259-0.891)$ ) showed a protective effect on iron deficiency anemia (IDA) when compared with normal weight. In our study it was found that women with underweight nutritional status had a higher risk of developing anemia while obese women had a lower risk of developing anemia, but this association could not be analyzed further because data regarding nutritional intake and ferritin levels were not available.

The results of the bivariate analysis showed that most of the women who were obese were using hormonal contraception. Research by Pratiwi et.al reported that the use of hormonal contraceptives was related to body weight, with an average increase in body weight of more than $0-1 \mathrm{~kg}$ per year among users of hormonal contraceptives. ${ }^{13}$ Women who use hormonal contraceptives usually also experience amenorrhea. ${ }^{14}$ This may put obese women at a lower risk of developing anemia. The results of studies in Rwanda and Tanzania also showed that users of hormonal contraceptives had a lower risk of developing anemia. ${ }^{15,16}$ This is consistent with our finding that women who use hormonal contraceptive have almost 50\% lower odds of having anemia.

In our study, malaria and tuberculosis infection were not found to be associated with anemia. Different information were found in Timor Leste ${ }^{17}$, 
Table 5. Adjusted odds ratio of anemia among WRA in Indonesia

\begin{tabular}{|c|c|c|c|}
\hline Variable & AOR & $95 \% \mathrm{Cl}$ & $\mathbf{p}$ \\
\hline \multicolumn{4}{|l|}{ Age (years) } \\
\hline $20-35$ & Ref. & & \\
\hline$<20$ & 3.444 & $2.216-5.351$ & $<0.001$ \\
\hline$>35$ & 0.858 & $0.696-1.053$ & 0.142 \\
\hline \multicolumn{4}{|l|}{ Education } \\
\hline High & Ref. & & \\
\hline Middle & 0.999 & $0.755-1.322$ & 0.995 \\
\hline Low & 0.819 & $0.604-1.111$ & 0.200 \\
\hline \multicolumn{4}{|l|}{ Employment status } \\
\hline Employed & Ref. & & \\
\hline Unemployed & 1.147 & $0.972-1.355$ & 0.105 \\
\hline \multicolumn{4}{|l|}{ Number of children } \\
\hline 0 & Ref. & & \\
\hline$>4$ & 0.95 & $0.058-1.501$ & 0.141 \\
\hline $3-4$ & 0.325 & $0.063-1.673$ & 0.179 \\
\hline $1-2$ & 0.431 & $0.080-2.313$ & 0.326 \\
\hline \multicolumn{4}{|l|}{ Nutritional status } \\
\hline Normal & Ref. & & \\
\hline Underweight & 1.484 & $1.075-2.050$ & 0.017 \\
\hline Overweight & 0.797 & $1.075-2.050$ & 0.058 \\
\hline Obese & 0.677 & $0.565-0.813$ & $<0.001$ \\
\hline \multicolumn{4}{|l|}{ Contraceptive ${ }^{*}$} \\
\hline None & Ref. & & \\
\hline IUD & 1.156 & $0.855-1.561$ & 0.346 \\
\hline Tubectomy & 0.876 & $0.594-1.292$ & 0.503 \\
\hline Hormonal & 0.528 & $0.438-0.636$ & $<0.001$ \\
\hline \multicolumn{4}{|l|}{ History of TB } \\
\hline No & Ref. & & \\
\hline Yes & 3.046 & $0.909-10.204$ & 0.071 \\
\hline \multicolumn{4}{|l|}{ Access to hospital } \\
\hline Easy & Ref. & & \\
\hline Difficult & 1.093 & $0.901-1.326$ & 0.368 \\
\hline Very difficult & 1.227 & $0.982-1.533$ & 0.071 \\
\hline \multicolumn{4}{|c|}{ Access to public health services } \\
\hline Easy & Ref. & & \\
\hline Difficult & 0.993 & $0.818-1.205$ & 0.942 \\
\hline Very difficult & 1.099 & $0.895-1.350$ & 0.369 \\
\hline
\end{tabular}

*bold=statistically significant relationship, $\mathrm{p} \leq 0.05$

Rwanda ${ }^{15}$, and Malawi. ${ }^{18}$ The difference in findings in our study was probably because the number of samples (respondents) who were positive for malaria and suffering from tuberculosis was very small. In the 2018 Riskesdas, data of the history of TB infection was collected only through interviews so that the incidence of $\mathrm{TB}$ was probably underreported by respondents.

Under the Balarajan framework for determinant of anemia, education, occupation and wealth are the underlying causes of anemia. ${ }^{5}$ In our study, however, education level, occupation, marital status, number of children, area of residence, access to health services and sources of drinking water were not related to anemia. In the bivariate analysis, it can be seen that the prevalence of anemia is significantly higher in WRA with a number of children $>4(31.9 \%)$ and WRA who do not have children $(42.3 \%)$ compared to WRA who have children $1-2$ and $3-4$, namely $25.2 \%$ and $25.4 \%$ respectively, but there was no relationship found in the multivariate analysis.

Varied results were found in studies conducted in Bangladesh ${ }^{19}$ and Rwanda. ${ }^{20}$ The study in Bangladesh reported that women with low education, working and living in rural areas are more likely to have anemia. ${ }^{19}$ Different results were found in Rwanda where there was no relationship between education and anemia but widows were more likely to have anemia. ${ }^{20}$ Research in Myanmar $^{21}$ found that high parity is more likely to be connected with anemia.

The limitation of this study is the use of secondary data where the analysis can only be done on the available variables. We were unable to assess the relationship between anemia and the socioeconomic condition of the respondents, nutritional intake, fortification, iron supplementation and infection by HIV and intestinal worms because data were not available. Socio-economic data is available in the National Socio-Economic Survey or Survey Sosial Ekonomi Nasional (Susenas) conducted by the Indonesia Statistics Agency or Badan Pusat Statistik (BPS) in the same year and for the same households as Riskesdas 2018 but no analysis was carried out in our study. In addition, this study is cross-sectional so that it cannot show a causal relationship.

\section{CONCLUSION}

Our study shows that the prevalence of anemia among WRA is a moderate public health problem. Factors associated with increased risk of anemia in WRA were age $<20$ years and underweight, while, obesity and use of hormonal contraception are found to reduce the risk of anemia. Interventions in controlling anemia in WRA need to be focused on the age group of $<20$ years and underweight as the group most at risk. This study did not differentiate between various types of anemia caused by factors such as vitamin B-12, folate, ferritin and parasitic infections. In addition, this study does not consider factors related to the consumption or intake of nutrients that have the potential to develop anemia such as socio-economic factors which are the important determinants of anemia, so in the future it is necessary to carry out research that takes these factors into account.

\section{ACKNOWLEDGEMENTS}

We would like to thank the Ministry of Health of The Republic of Indonesia for the permission given to enable secondary data analysis of the 2018 Riskesdas, Udayana University and all parties who have contributed to this study. 


\section{AUTHOR CONTRIBUTION}

PSU designed and conceived the study, analyzed the data, wrote the first draft of the manuscript and edited the manuscript. LSA, DSL and DNW were involved in the design and conception of the study, provided feedback and edited the manuscript.

\section{CONFLICT OF INTEREST STATEMENT}

None declared

\section{REFERENCES}

1. World Health Organization. Worldwide prevalence of anaemia 1993-2005: WHO Global Database on Anemia [Internet]. Word Health Organization; 2008. Available from: https://www.who.int/vmnis/publication/anemia prevalence/en/

2. World Health Organization. The global prevalence of anaemia in 2011 [Internet]. World Health Organization; 2015. Available from: https://apps.who.int?iris/ hendle/10665/177094

3. World Health Organization. WHO Global Nutrition Targets 2025: Anaemia policy brief [Internet]. 2014 p. 1-7. Available from: https://www.who.int/nutrition/ publications/globaltargets2025_policybrief_anaemia/en

4. World Bank. Prevalence of anemia among women of reproductive age (\% of women ages 15-49) [Internet]. Vol. 19, The World Bank. 2016. Available from: https:// data.worldbank.org/indicator/SH.ANM.ALLW. ZS?locations $=\mathrm{MN}$

5. Balarajan Y, Ramakrishnan U, Özaltin E, Shankar AH, Subramanian S V. Anaemia in low-income and middleincome countries. Lancet. 2011;378(9809):2123-2135.

6. Ministry of Health of the Republic of Indonesia. Hasil Utama Riskesdas 2018 [Main results of the 2018 Riskesdas]. Jakarta; 2018.

7. Gautam S, Min H, Kim H, Jeong HS. Determining factors for the prevalence of anemia in women of reproductive age in Nepal: Evidence from recent national survey data. PLoS One. 2019;14(6):1-17

8. Guspaneza E, Martha E. Analisis faktor penyebab kejadian anemia pada ibu hamil di Indonesia (Analisis data SDKI 2017) [Analysis of factors influencing anemia among pregnant mothers in Indonesia (Analysis of the 2017 SDKI data]. J Kesehat Masy Aceh. 2019;5(2):399-406.

9. Dey S, Goswami S, Goswami M. Prevalence of anaemia in women of reproductive age in Meghalaya: A logistic regression analysis. Turkish J Med Sci. 2010;40(5):783-789.

10. Haralkar SJ, Khandekar SV, Pore PD, Haralkar AS, Tapare VS, Rayate MV. Socio-demographic correlates of anaemia among married women in rural area of Maharashtra. Indian J Public Heal Res Dev. 2013;4(3):107-110.
11. Qin Y, Melse-Boonstra A, Pan X, Yuan B, Dai Y, Zhao $\mathrm{J}$, et al. Anemia in relation to body mass index and waist circumference among Chinese women. Nutr J. 2013;12(1):10-12.

12. Chang JS, Chen YC, Owaga E, Palupi KC, Pan WH, Bai $\mathrm{CH}$. Interactive effects of dietary fat/carbohydrate ratio and body mass index on iron deficiency anemia among Taiwanese women. Nutrients. 2014;6(9):3929-3941.

13. Pratiwi D, Syahredi S, Erkadius E. Hubungan antara penggunaan kontrasepsi hormonal suntik DMPA dengan peningkatan berat badan di Puskesmas Lapai Kota Padang [The association between the use of injected hormonal contraception DMPA and body weight increase in Lapai Public Health Center, Padang City]. Jurnal Kesehatan Andalas. 2014;3(3):365-369.

14. Hartanto H. Keluarga berencana dan kontrasepsi [Family planning and contraception]. Jakarta: Pustaka Sinar Harapan; 2004.

15. Hakizimana D, Nisingizwe MP, Logan J, Wong R. Identifying risk factors of anemia among women of reproductive age in Rwanda-A cross-sectional study using secondary data from the Rwanda Demographic and Health Survey 2014/2015. BMC Public Health. 2019;19(1):1-11.

16. Wilunda C, Massawe S, Jackson C. Determinants of moderate-to-severe anaemia among women of reproductive age in Tanzania: Analysis of data from the 2010 Tanzania Demographic and Health Survey. Trop Med Int Heal. 2013;18(12):1488-1497.

17. Lover AA, Hartman M, Chia KS, Heymann DL. Demographic and spatial predictors of anemia in women of reproductive age in Timor-Leste: Implications for health program prioritization. PLoS One. 2014;9(3).

18. Chaparro CM, Suchdev PS. Anemia epidemiology, pathophysiology, and etiology in low- and middle-income countries. Ann N Y Acad Sci. 2019;1450:15-31.

19. Kamruzzaman M, Rabbani MG, Saw A, Sayem MA, Hossain MG. Differentials in the prevalence of anemia among non-pregnant, ever-married women in Bangladesh: Multilevel logistic regression analysis of data from the 2011 Bangladesh Demographic and Health Survey. BMC Womens Health. 2015;15(1):4-11.

20. Hakizimana D, Nisingizwe MP, Logan J, Wong R. Risk factors of anemia among women of reproductive age in Rwanda: Implications for designing better interventions. BMC Public Health (Pre-print). 2019.

21. Win HH, Ko MK. Geographical disparities and determinants of anaemia among women of reproductive age in Myanmar: Analysis of the 2015-2016 Myanmar Demographic and Health Survey. WHO South-East Asia J Public Heal. 2018;7(2):107-113.

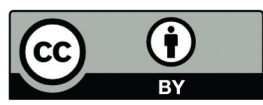

This work is licensed under a Creative Commons Attribution 